\title{
RIWAYAT PEMBERIAN ASI EKSKLUSIF DAN PERTUMBUHAN BALITA PADA USIA 12 BULAN DI DESA CIKUNIR KECAMATAN SINGAPARNA KABUPATEN TASIKMALAYA TAHUN 2015
}

Oleh :

Erwina Sumartini, S.ST

\section{A. Abstrak}

Pertumbuhan dan perkembangan anak merupakan aspek terpenting dari kehidupan seseorang, karena menentukan dasar untuk kehidupan selanjutnya. Faktor yang berpengaruh terhadap tumbuh kembang anak adalah gizi, penyakit kronis/ kelainan kongenital, lingkungan fisik dan kimia, psikologis, endokrin, sosio-ekonomi, lingkungan pengasuhan, stimulasi, danobat-obatan. ASI eksklusif merupakan makanan paling ideal untuk memenuhi kebutuhan gizi bayi. Desa Cikunir merupakan salah satu desa yang masih memiliki balita dengan gizi buruk sebanyak 2 balita (0,5\%) pada tahun 2014, dan balita dengan berat badan dibawah garis merah sebanyak 10 balita (2,3\%). Melihat data tersebut kondisi pertumbuhan bayi di Desa Cikunir masih memerlukan perhatian yang serius. Cakupan pemberian ASI eksklusif di wilayah kerja Puskesmas Singaparna sebesar 84,5\% dan cakupan ASI eksklusif di Desa Cikunir pada tahun 2014 baru mencapai $50 \%$.

Jenis penelitian yang digunakan adalah kuantitatif dengan metode deskriptif. Populasi penelitian adalah seluruh balita di Kp. Margamulya yang telah melewati usia 12 bulan, dengan pengambilan sampel menggunakan accidental sampling dengan jumlah 30 orang. Analisis yang digunakan adalah analisis univariat.

Berdasarkan hasil penelitian menunjukan bahwa 83,3\% balita mendapatkan ASI eksklusif dan 16,7\% tidak mendapatkan ASI eksklusif. 56,7\% mengalami pertumbuhan dengan kategori sesuai pada usia 12 bulan dan 43,3\% memiliki kategori pertumbuhan tidak sesuai. $60 \%$ balita yang tidak mendapatkan ASI eksklusif mengalami pertumbuhan dengan kategori tidak sesuai pada usia 12 bulan.

Berdasarkan hasil penelitian tersebut disimpulkan bahwa ASI eksklusif memegang peranan penting terhadap pertumbuhan balita, karena komposisi ASI yang sangat pas untuk kebutuhan bayi sehingga akan dapat meminimalisir gangguan kesehatan pada bayi, dengan demikian pertumbuhan bayi tidak mengalami hambatan. Saran untuk ibu yang mengalami sindrom ASI sedikit segera konsultasi dengan tenaga kesehtan untuk mendapatkan solusi yang tepat sehingga pemberian ASI eksklusif dapat dilanjutkan. Bidan harus meningkatkan peyuluhan dan konseling pada ibu yang mempunyai bayi dan melakukan pemantauan pertumbuhan untuk segera mendeteksi hambatan pertumbuhan.

\section{Kata Kunci: ASI eksklusif, Pertumbuhan, Balita}




\section{B. Latar Belakang}

Secara nasional prevalensi balita gizi buruk menurun sebanyak 0,5 persen yaitu dari 18,4 persen pada tahun 2007 menjadi 17,9 persen pada tahun 2010 . Demikian halnya dengan prevalensi balita pendek yang menurun sebanyak 1,2 persen yaitu dari 36,8 persen pada tahun 2007 menjadi 35,6 persen pada tahun 2010, dan prevalensi balita kurus menurun sebanyak 0,3 persen yaitu dari 13,6 persen pada tahun 2007 menjadi 13,3 persen pada tahun 2010. (RISKESDAS, 2010).

Pertumbuhan dan perkembangan pada anak merupakan aspek terpenting dari kehidupan seseorang, karena menentukan dasar untuk kehidupan selanjutnya. Banyak persepsi orang tua yang dinilai kurang tepat tentang anak mereka, mereka menganggap selama anak tidak sakit, berarti anak tidak mengalami masalah kesehatan termasuk pertumbuhan dan perkembangannya. Sehingga tidak perlu dibawa ke petugas kesehatan untuk diperiksa. Akibat persepsi tersebut banyak orang tua yang tidak mengutamakan anaknya dipantau tumbuh kembangnya ke Posyandu terutama pada anak diatas 1 tahun karena telah melewati usia wajib imunisasi dasar.

Pertumbuhan adalah bertambahnya ukuran fisik (anatomi) dan struktur tubuh dalam arti sebagian atau seluruhnya karena adanya multiplikasi (bertambah banyak) sel-sel tubuh dan juga disebabkan oleh bertambah besarnya sel. Sedangkan perkembangan adalah bertambahnya kemampuan dan struktur/fungsi tubuh lebih kompleks dalam pola yang teratur, serta dapat diperkirakan dan diramalkan sebagai hasil proses diferensiasi sel, jaringan tubuh, organ-organ, dan sistem yang terorganisasi.

Tumbuh kembang seorang anak dimulai dari masa konsepsi sampai berusia 18 tahun. Diantara masa tersebut lima tahun pertama kehidupan merupakan masa keemasan (golden periode), pada masa tersebut seorang anak harus mengalami pertumbuhan dan perkembangan secara optimal, agar anak bisa menjadi manusia yang berkualitas dimasa selanjutnya. Pola pertumbuhan dan perkembangan anak umumnya merupakan interaksi banyak faktor yang saling mempengaruhi. Faktor yang mempengaruhi tumbuh kembang dapat dikelompokan menjadi faktor internal dan eksternal. Faktor internal meliputi genetik dan pengaruh hormon, sedangkan faktor eksternal meliputi faktor pranatal, faktor kelahiran/persalinan dan faktor pascanatal (susilaningrum, dkk.2013).

Seperti halnya pada masa pranatal, faktor yang berpengaruh terhadap tumbuh kembang anak adalah gizi, penyakit kronis/kelainan kongenital, lingkungan fisik dan kimia, psikologis, endokrin, sosio-ekonomi, lingkungan pengasuhan, stimulasi, dan obat-obatan. Seorang anak dapat tumbuh dan berkembang secara optimal dipengaruhi oleh hasil interaksi antara faktor genetik, herediter, konstutusi, dan faktor lingkungan. Faktor gizi yang sangat berpengaruh terhadap tumbuh kembang adalah pemberian ASI eksklusif, karena ASI merupakan makanan yang paling ideal bagi bayi 0-6 bulan sehingga dengan pemberian ASI kekebalan tubuh bayi akan lebih baik dan pertumbuhan bayi tidak akan berlangsung dengan baik tanpa dihambat oleh gangguan kesehatan. Sehingga bayi dan balita yang mendapatkan ASI secara eksklusif biasanya akan mengalami pertumbuhan dan perkembangan yang baik pula.

Pada tahun 2014 jumlah balita dengan gizi buruk di wilayah kerja Puskesmas Singaparna berjumlah 11 balita dan balita dengan berat badan dibawah garis merah sebanyak 155 orang $(5,3 \%)$. Desa Cikunir merupakan salah satu desa yang masih memiliki balita dengan gizi buruk sebanyak 2 balita $(0,5 \%)$ pada tahun 2014 , dan 
balita dengan berat badan dibawah garis merah sebanyak 10 balita (2,3\%). Melihat data tersebut kondisi pertumbuhan bayi di Desa Cikunir masih memerlukan perhatian yang serius. Cakupan pemberian ASI eksklusif di wilayah kerja Puskesmas Singaparna sebesar $84,5 \%$ dan cakupan ASI eksklusif di Desa Cikunir pada tahun 2014 baru mencapai $50 \%$ (Rahmawati, 2015). Melihat masih

\section{Metode}

Jenis peneliltian ini termasuk kuantitatif dengan menggunakan metode deskrtiptif. Populasi dalam penelitian ini adalah seluruh balita yang telah melebihi usia 12 bulan yang melakukan penimbangan di Posyandu. Sampel menggunakan accidental sampel dengan jumlah sampel 30 orang.

Jenis data dalam penelitian ini berupa data primer dan data sekunder. Data primer digunakan untuk mengetahui riwayat pemberian ASI eksklusif dengan menggunakan kuesioner yang dibagikan kepada ibu yang mempunyai balita yang berkunjung ke posyandu. Untuk data pertumbuhan diguanakan data sekunder dengan melihat hasil penimbangan bulanan pada KMS, yang dilihat adalah data berat banyaknya bayi yang tidak mendapatkan asi secara eksklusif maka peneliti tertarik untuk melakukan penelitian riwayat pemberian ASI eksklusif dan pertumbuhan balita pada usia 12 bulan di Kp. Margamulya Desa Cikunir Kecamatan Singaparna Kabupaten Tasikmalaya Tahun 2015. Adapun alasan pemilihan Kp. Margamulya karena termasuk dusun binaan STIKes Respati Tasikmalaya.

badan lahir dan berat badan pada saat anak mencapai usia 12 bulan.

Setelah data terkumpul, peneliti melakukan editing yaitu memeriksa kembali data-data yang telah terkumpul dan melengkapi data yang masih kurang dengan meminta data kembali pada kader kesehatan. Setelah data dilengkapi data dikategorikan sesuai dengan pengkategorian yang telah dibuat pada masing-masing variavel yang diteliti dan selanjutnya melakukan tabulasi data.

Analisis univariat dilakukan untuk mendeskripsikan data dari hasil tabulasi. Selanjutnya dianalisis dan disesuaikan teori yang ada dengan menggunakan rumus sebagai berikut:

$$
P=\frac{n}{N} x 100 \%
$$

\section{Hasil Penelitian}

Riwayat Pemberian ASI eksklusif

Tabel 5.1

Distribusi frekuensi riwayat pemberian ASI eksklusif pada Balita di Kp. Margamulya Desa Cikunir Kecamatan Singaparna Kabupaten Tasikmalaya

Tahun 2015

\begin{tabular}{|l|c|c|}
\hline \multicolumn{1}{|c|}{$\begin{array}{c}\text { Pemberian ASI } \\
\text { Eksklusif }\end{array}$} & Jumlah & Persentase \\
\hline ASI eksklusif & 25 & 83,3 \\
\hline Tidak ASI eksklusif & 5 & 16,7 \\
\hline Total & 30 & 100.0 \\
\hline
\end{tabular}

Berdasarkan tabel 5.1 menunjukkan bahwa sebagian besar balita diberikan asi secara eksklusif sebanyak $83,3 \%$ ( 25 balita). 


\section{Pertumbuhan Balita Pada Usia 12 Bulan}

Tabel 5.2

Distribusi frekuensi pertumbuhan balita pada umur 12 bulan di Kp. Margamulya Desa Cikunir Kecamatan Sukarame Kabupaten Tasikmalaya Tahun 2015

\begin{tabular}{|l|c|c|}
\hline Pertumbuhan Balita & Jumlah & Persentase \\
\hline Sesuai & 17 & 56,7 \\
\hline Tidak sesuai & 13 & 43,3 \\
\hline Total & 71 & 100.0 \\
\hline
\end{tabular}

Berdasarkan tabel 5.2 menunjukkan bahwa $43,3 \%$ balita mengalami pertumbuhan tidak sesuai pada saat umur 12 bulan.

\section{E. Pembahasan}

\section{Riwayat Pemberian ASI Ekslusif}

Berdasarkan data hasil penelitian sebagian besar balita mendapatkan asi secara ekslusif yaitu sebanyak $83,3 \%$ dan sebagian kecil tidak mendapatkan asi secara eksklusif yaitu sebanyak 16,7\%.

Apabila melihat data diatas terdapat $16,7 \%$ balita tidak mendapatkan ASI eksklusif. ASI merupakan makanan yang paling baik bagi bayi sampai umur 6 bulan, karena bayi pada saat berumur 6 bulan system pencernaannya mulai matur. Jaringan pada usus halus bayi pada umumnya seperti saringan pasir, poriporinya berongga sehingga memungkinkan bentuk protein ataupun kuman akan langsung masukd alam system peredaran darah dan dapat menimbulkan alergi. Pori-pori dalam usus bayi ini akan tertutup rapat setelah bayi berumur 6 bulan. Dengan demikian, usus bayi setelah berumur 6 bulan mampu menolak factor alergi ataupun kuman yang masuk (Kristiyansari, 2009).

Apabila melihat teori diatas, bayi yang tidak mendapatkan ASI secara eksklusif mempunyai peluang lebih besar terhadap gangguan masalah kesehatan seperti diare ataupun penyakit yang lain dibanding bayi yang mendapatkan ASI secara eksklusif, hal tersbut dikarenakan makanan yang paling pas dengan sistem pencernaan bayi hanyalah ASI saja. Selain itu ASI juga memberikan banyak keuntungan bagi pertumbuhan dan perkembangan bayi dikemudian hari karena ASI memiliki banyak kelebihan dibandingkan dengan susu botol. ASI menyediakan zat-zat gizi yang diperlukan bayi dalam bentuk yang paling mudah dicerna dan paling mudah diserap. ASI mengandung anti bodi dan sel-sel darah putih yang melindungi bayi terhadap infeksi. ASI bisa mengubah keasaman tinja dan flora usus sehingga melindungi bayi terhadap diare karena bakteri (Ronald. 2011). Melihat begitu banyak keuntungan yang diperoleh dari ASI, maka pertumbuhan dan perkembangan bayi dikemudian hari akan baik pula.

Berdasarkan data yang diperoleh $16,7 \%$ ibu yang tidak memberikan ASI secara eksklusif beralasan bahwa ASInya sedikit sehingga tidak mencukupi untuk kebutuhan bayi. Sindrom ASI kurang sering menjadi masalah selama periode laktasi, sering kenyataannya ASI tidak benar-benar kurang. Tanda-tanda yang mungkin saja ASI benar-benar kurang antara lain : bayi tidak puas setiap setelah menyusui, sering sekali menyusu, menyusu dengan waktu yang sangat lama. Tapi juga terkadang bayi lebih cepat menyusu. Disangka produksinya berkurang padahal dikarenakan bayi telah pandai menyusu. Bayi sering menangis atau bayi menolak menyusu. Tanda bahwa ASI benar-benar kurang, antara lain: berat badan bayi meningkat kurang dari rata-rata 500 gram perbulan. Berat badan lahir dalam waktu 2 minggu belum 
kembali. Ngompol rata-rata kurang dari 6 kali dalam 24 jam (Kristiyansari, 2009). Cara mengatasinya disesuaikan dengan penyebab, terutama dicari pada ke 4 kelompok faktor penyebab, yaitu faktor teknik menyusui, faktor psikologis, faktor fisik ibu (kontrasepsi, diuretik, hamil, merokok dan kurang gizi), faktor kondisi bayi misalnya abnormalitas (sangat jarang). (Kristiyansari, 2009)

\section{Pertumbuhan Balita Pada Usia 12 Bulan}

Berdasarkan data hasil penelitian $56,7 \% \quad(17$ balita $)$ mengalami pertumbuhan sesuai pada usia 12 bulan dan 43,3\% (13 balita) mengalami pertumbuhan tidak sesuai.

Menurut IDAI (2002) yang dikutip oleh Susilaningrum, dkk (2013;35) mengatakan bahwa pertumbuhan adalah bertambahnya ukuran fisik (anatomi) dan struktur tubuh dalam arti sebagian atau seluruhnya karena adanya multiplikasi (bertambahbanyak) sel-sel tubuh dan juga disebabkan oleh bertambah besarnya sel. Salah satu indikator untuk mengetahui pertumbuhan bayi adalah dengan melakukan pengukuran berat badan dan tinggi badan dan disesuaikan dengan standar berat badan berdasarkan umur balita. Berdasarkan data hasil penelitian terdapat $43,3 \%$ balita yang mengalami pertumbuhan tidak sesuai pada usia 12 bulan. Data tersebut menunjukan bahwa pertumbuhan balita tersebut mengalami hambatan sehingga berat badan pada usia 12 bulan tidak mencapai 3 kali berat badan lahir. Pertumbuhan dan perkembangan dipengaruhi oleh beberapa faktor, diantaranya : faktor dalam (internal) dan faktor luar (eksternal). Faktor eksternal diantaranya faktor pranatal, faktor persalinan dan paktor pasca persalinan. Salah satu faktor pasca persalinan yang mempengaruhi pertumbuhan dan perkembangan bayi adalah gizi setelah bayi dilahirkan. Idealnya bayi mendapatkan ASI secara eksklusif selama 6 bulan pertama,
NAMUN padakenyataannya, $60 \%$ bayibelumberumur 4 bulan sudah mendapat tambahan susu sapi (Kristiyansari, 2009).

Apabila mengingat sistem pencernaan bayi baru matur setelah 6 bulan sangat wajar apabila pertumbuhan bayi yang tidak mendapatkan ASI eksklusif mengalami hambatan. Hal ini sesuai dengan data hasil penelitian dari 5 balita yang tidak mendapatkan ASI eksklusif $60 \%$ termasuk kategori pertumbuhan tidak sesuai. selain faktor gizi (ASI eksklusif), pertumbuhan dan perkembangan juga dipengaruhi oleh faktor lain misalnya bayi mengalami penyakit kronis, lingkungan pengasuhan ataupun faktor lain. Selain faktor dalam dan luar untuk menunjang pertumbuhan dan perkembangannya bayi juga membutuhkan pemenuhan akan kebutuhan dasar asuh, asih dan asah. Kebutuhan asuh meliputi pemenuhan nutrisi yang adekuan dan seimbang, perawatan kesehatan dasar, pakaian, perumahan, higiene diri dan lingkungan serta kesegaran jasmani. Kebutuhan asih meliputi : kasih sayang orang tua, rasa aman, harga diri, dukungan/dorongan, mandiri, rasa memiliki dan kebutuhan akan sukses serta mendapatkan kesempatan dan pengalaman. Kebutuhan asah yaitu kebutuhan akan stimulasi.

Melihat data penunjang penelitian terdapat 3 balita yang tidak rutin datang ke posyandu dengan alasan ibu dari 2 balita mengatakan malas datang ke posyandu sedangkan 1 ibu balita mengatakan sibuk bekerja karena ibu berprofesi sebagai pengajar di sekolah dasar. Dilihat dari data pertumbuhan 1 dari balita yang tidak rutin datang ke posyandu mengalami pertumbuhan tidak sesuai pada usia 12 bulan.

Melihat data hasil penelitian dapat diatirk kesimpulan bahwa masih banyak balita yang mengalami pertumbuhan tidak sesuai pada umur 12 bulan yang disebabkan oleh berbagai faktor diantaranya tidak diberikan ASI secara 
eksklusif maupun oleh faktor lainnya. Masih terdapat ibu yang tidak memberikan ASI secara eksklusif dikarenakan faktor sindrom ASI kurang. Untuk mengatasi masalah sindrom ASI kurang ibu balita dapat segera berkonsultasi kepada tenaga kesehatan untuk mendapatkan penjelasan sehingga

\section{F. Simpulan dan saran}

Berdasarkan hasil penelitian mengenai gambaran riwayat pemberian ASI eksklusif dengan pertumbuhan Balita pada Usia 12 Bulan di Kp. Margamulya Desa Cikunir Kecamatan Singaparna Kabupaten Tasikmalaya Tahun 2015, maka dapat ditarik kesimpulan :

1. Sebagian besar balita mendapatkan ASI secara eksklusif yaitu sebesar $83,3 \%$.

2. Balita dengan kategori pertumbuhan tidak sesuai pada umur 12 bulan sebanyak 43,3\%.

\section{Saran}

1. Bagi Ibu Balita

Ibu yang mempunyai bayi 0-6 bulan hendaknya segera berkonsultasi kepada tenaga kesehatan apabila mengalami sindrom ASI kurang, agar masalah segera teratasi dan pemberian ASI secara eksklusif dapat terus dilanjutkan.

2. BagiBidan Desa

Bidan desa diharapkan dapat menggalakan kembali penyuluhan ataupun konseling pada ibu yang mempunyai bayi 0-6 bulan untuk terus memberikan ASI secara eksklusif dan melakukan pemantauan pertumbuhan bayi dan balita secara rutin ke Posyandu.

3. Dilakukan penelitian pertumbuhan dan perkembangan dengan indikator yang lebih lengkap dan melihat lebih banyak lagi faktor yang berpengaruh terhadap pertumbuhan dan perkembangan. bisa memperbaiki kondisi ASI yang kurang. Ibu dan bayi dapat saling membantu agar produksi ASI meningkat dan bayi terus memberikan isapan efektifnya. Pada keadaan keadaan tertentu dimana produksi ASI memang tidak memadai maka perlu upaya lebih, misalnya dengan relaksasi.

\section{G. Referensi}

Kemenkes RI, 2012. Pedoman Pelaksanaan Stimulasi, Deteksi dan Intervensi Dini Tumbuh Kembang Anak di Tingkat Pelayanan Kesehatan Dasar. Jakarta

Kristiyansari, 2009. ASI, Menyusui \& Sadari. Nuha Medika. Yogyakarta Nugroho, 2011.ASI dan Tumor Payudara. Nuha Medika. Yogyakarta

Nutrisi bangsa. 2012. 28\% Anak Indonesia Kurang Giz. http://nutrisiuntukbangsa.org/28anak-indonesia-kurang-gizi/

Ronald H.S, 2011. Pedoman \& Perawatan Balita Agar Tumbuh Sehat dan Cerdas. Nuansa Aulia. Bandung.

Sudarti dan Khoerunisa, 2010. Asuhan Kebidanan Neonatus, Bayi dan Anak Balita. Nuha Medika. Yogyakarta.

Susilaningrum dkk, 2013). Asuhan keperawatan Bayi dan Anak untuk Perawat dan Bidan. Salemba Medika. Jakarta

Rahmaniar. 2011. Trend Kasus Gizi Buruk di Tasikmalaya. ahligizibercerita.blogspot.com/.../ trend-kasus-gizi-bur.

Rahmawati. 2015. Analisis Situasi Kesehatan Ibu Hamil dengan Anemia di Puskesmas Singaparna Kecamatan Singaparna Kabupaten Tasikmalaya. Laporan praktik kesehatan masyarakat III (Tidak dipublikasikan). STIKes Respati Tasikmalaya 